\title{
States as Gender Equality Activists: The Evolution of Quota Laws in Latin America
}

\author{
Jennifer M. Piscopo
}

\begin{abstract}
This article examines two decades of strengthening, expansion, and diffusion of gender quota laws in Latin America. The analysis departs from studies of quotas' adoption, numerical effectiveness, or policy impacts, instead focusing on states' use of coercive power to integrate women into public and private institutions. Viewing these policies in light of feminist theories of the poststructuralist state reveals how state institutions act to restructure government and promote gender equality. In building this argument, the article presents an up-to-date empirical survey and conceptual understanding of quota evolution in Latin America, including recent developments in countries such as Chile, Colombia, Bolivia, Ecuador, Mexico, Nicaragua, and Uruguay.
\end{abstract}

T ender quota laws mandate that political parties nominate specified percentages of women for public office. Argentina adopted the first statutory gender quota for legislative offices in 1991. Before Argentina's innovative reform, some political parties in Europe, Latin America, and elsewhere had internally committed to nominate specified percentages of women. Argentina became the first country to elevate an internal party strategy to a national legal mandate, and countries across Latin America (and the globe) soon followed. Quotas demonstrated Latin American states' willingness to manufacture women's political inclusion and, as such, raised expectations about the political and social outcomes that would follow.

Consequently, scholarship on gender quotas in Latin America has flourished in the past two decades. Researchers and activists concur that quotas, when properly designed and enforced, remain the most effective way to raise women's numerical presence in Latin American legislatures (Dahlerup and Freidenvall 2005; Jones 2004, 2009; Schwindt-Bayer 2009). Studies examining women's integration into political power structures have also looked beyond the numbers, generating a "skeptical narrative" centered on two critiques. First, scholars highlight how the laws' numerous loopholes and lax oversight have created opportunities for elites to subvert quotas. These manipulations, occurring even in numerically successful cases, allow elites to violate either the letter or the spirit of the law (Baldez 2007; Htun and Jones 2002; Hinojosa 2012). Second, quotas have been unable to guarantee

Jennifer M. Piscopo is an assistant professor of politics at Occidental College. piscopo@oxy.edu 
feminist policy change, let alone erode the patriarchal practices that hinder women's genuine political empowerment. This critique appears where quotas have approached their numerical targets (Franceschet and Piscopo 2008; Sagot 2010; Zetterberg 2008) and where they have fallen dramatically short (Miguel 2012; Zetterberg 2008).

These critiques focus on party elites' shirking behavior, meaning their reluctance to redistribute political power to women, whether via nominations or via legislative authority. Yet I argue that this "skeptical narrative" overlooks the role Latin American states have played in countering elite resistance and improving women's access to policy power. Most quota scholarship from Latin America explains the measures' adoption or numerical effects (Bush 2011; Crocker 2011; Jones 2009; SchwindtBayer 2009; Paxton et al. 2010; Thames and Williams 2013) or analyzes implementation using single cases (see chapters in Franceschet et al. 2012; Crocker 2011). This article, by contrast, takes a regional view and focuses on the role of the state.

First-generation gender quota laws were policies promoted by specific governments, but once passed, their normative commitments and specific regulatory provisions became installed within the state. Feminist scholars' theories of the poststructuralist state thus provide a novel lens through which to assess the quota reforms that followed. Through conceptualizing the state as a set of arenas in which struggles over policy innovation and policy implementation occur (Pringle and Watson 1998; Randall 1998; Waylen 1998), poststructualism offers an optimistic take on the forward march of women's political inclusion. Myriad state institutions in Latin America, from legislatures to electoral tribunals and constitutional courts, have acted to improve—rather than unravel—-the region's quota laws.

Two decades of quota evolution thus show that states are doing more than passively acknowledging women's political rights. Although no Latin American country met the quota threshold in its first post-quota election, multiple state institutions have undertaken three interrelated processes of reform. Strengthening improves quota performance by closing loopholes and raising thresholds; expansion continues this trend, using jurisprudence and imposing additional regulations to make quotas permanent features of the political landscape. Together, strengthening and expansion combat elite shirking behavior. Diffusion adopts and applies quotas to political institutions beyond national legislatures.

States' readiness to undertake these wide-ranging reforms may initially seem counterintuitive, especially when reforms are led by legislators or executives: the very leaders pushing quotas forward could themselves become forced to vacate their seats for women. Yet an analysis based in the poststructuralist state shifts the perspective away from individual governments' strategic objectives and toward the constraints posed by the broader institutional setting, meaning constitutions, statutes, and equality discourses (Pringle and Watson 1998; Kantola 2006; Hawkesworth 2012). Gender quotas in Latin America have been backed by domestic and international commitments that frame gender equality as a positive right, and these commitments demand more than simply ensuring that women can seek redress when rights are violated. Instead, these commitments guarantee women's political inclusion, and 
leaders in and across state institutions, from electoral officials to national legislators, become obligated to further realize this positive right, even if it means vacating their own seats.

This article thus counters the skeptical narrative by focusing on state institutions' role in quota evolution, offering an optimistic narrative that retheorizes Latin American states as active promoters of gender equality. It presents evidence of states' strengthening, expansion, and diffusion of gender quotas through primary sources (quota statutes, equality laws, constitutions, judicial rulings, domestic newspaper accounts, and field interviews). It considers quota trajectories across the region as a whole but places particular emphasis on new and unstudied developments, including recently adopted quotas in Chile, Colombia, El Salvador, Nicaragua, and Uruguay; the shift from quotas to parity in seven countries; the regulation of political parties' practices in regard to the recruitment and promotion of women; and quota laws for the executive branch, the judicial branch, and civil society organizations. The last two trends remain underanalyzed in scholarly work, and this article offers the first regionwide documentation of nonlegislative affirmative action measures in Latin America.

Furthermore, accounting for recent developments supports this article's theorybuilding exercise: the sheer number of state institutions that have acted to forcibly alter officeholding patterns across politics and society provides evidence against throwing quotas out with the proverbial bathwater. Despite their limitations, quotas' evolution demonstrates that Latin American states have established and maintained a feminist commitment to restructuring the distribution of policy power.

This article proceeds as follows. First, it draws on the gender and politics literature, particularly feminist theories of the state, to conceptualize how states behave as gender equality activists: once installed in the state through activist pressure and government acquiescence, quotas create spaces where women and their allies can enact further improvements from inside the state. Second, it analyzes the strengthening of quota laws at the national level, drawing especially on new and recent developments. Then it reviews the skeptical narrative in light of quota expansion, arguing that myriad state institutions have improved quotas' performance by making the measures permanent, heavily regulated features of democracy. It supports this argument by documenting quota diffusion to subnational legislatures, other government branches, and civil society. Throughout, the word quotas refers to gender quota laws (rather than voluntary practices). The article concludes that quota strengthening, expansion, and diffusion reveal Latin American states acting to positively guarantee women's access to public life. 


\section{Gender Quotas AND THE STATE IN LATIN AMERICA}

Past quota scholarship has been instrumental in demonstrating how Latin America became the vanguard for mandating women's legislative representation. Beginning with Argentina in 1991, governments across the region rapidly adopted quotas, with scholars identifying the joint importance of the following factors: international spotlighting through the United Nations' world conferences on women, particularly the 1995 Beijing conference; the domestic and regional mobilization of quota proponents, typically female party activists, feminist movements, women's movements, and female legislators; supportive chief executives; and the opportunities for policy innovation sparked by democratization, which encouraged countries to quickly close the electoral gender gap (Bush 2011; Crocker 2011; Dahlerup and Freidenvall 2005; Krook 2009; Sacchet 2008; Thames and Williams 2013; Towns 2012). These same variables also influenced quotas' adoption at the subnational level in Argentina and Mexico.

Yet not all first-generation quotas were created equal (Krook 2009). Scholars have also leveraged cross-national, subnational, and over-time variation in quota design to establish which electoral and statutory features matter for numerical success. These include high thresholds; placement mandates for electoral lists, especially in closed-list proportional representation systems; and sanctions for noncompliance (Jones 1996, 1998, 2004; Schwindt-Bayer 2009). As table 1 shows, the combination of these features largely explains which Latin American cases come within ten percentage points or better of their target (Argentina, Bolivia, Ecuador, Mexico, Paraguay, and Peru) and which cases find their targets barely attainable (Brazil and Panama).

This research has thus yielded important conclusions about best practices for raising women's numerical representation in the legislature. Nonetheless, Franceschet and Piscopo note that the "use of state power to attain this goal has remained undertheorized by comparative politics scholars" (2013, 313). Studies of gender equality and the Latin American state have more typically centered on executive branch women's policy agencies or on state institutions' effective delivery of government policy. For example, scholars have evaluated whether women's policy agencies can ally with activist groups to deliver antiviolence protections (Franceschet 2010; Weldon 2002), or whether state institutions facilitate family law reform (Htun 2003). Yet gender quotas-because they are legal statutes whose normative commitments and regulatory requirements become part of the state apparatus - also invoke state power. Indeed, as feminist mobilization in civil society has declined and as welfare regimes have eroded, feminist scholars view the state as the primary vehicle for attaining reforms that advance gender equality (Jaquette 2009, 11).

What analytical leverage does a state-centered analysis provide in the context of gender quotas? On the one hand, a key insight from feminist scholarship is that state institutions sanitize progressive policies, thus perpetuating sexual inequality in the public and private spheres. For example, Alvarez's pathbreaking study on Brazil con- 
Table 1. Women's Representation in Latin American Countries with Quotas, June 2015

\begin{tabular}{lclcc}
\hline \hline & Election & \multicolumn{1}{c}{$\begin{array}{c}\text { Quota in Effect } \\
(\%)\end{array}$} & $\begin{array}{c}\text { Lower House } \\
(\%)\end{array}$ & $\begin{array}{c}\text { Senate } \\
(\%)\end{array}$ \\
\hline Argentina & 2013 & Both chambers, 30 & 36.2 & 38.9 \\
Bolivia & 2014 & Both chambers, 50 & 53.1 & 47.2 \\
Brazil & 2014 & Lower chamber, 30 & 9.9 & 16.0 \\
Colombia & 2014 & Both chambers, 30 & 19.9 & 22.5 \\
Costa Rica & 2014 & Unicameral, 50 & 33.3 & \\
Dominican Republic & 2010 & Lower chamber, 33 & 20.8 & \multirow{2}{*}{9.4} \\
Ecuador & 2013 & Unicameral, 50 & 41.6 & \\
Honduras & 2013 & Unicameral, 40 & 25.8 & \\
Mexico & 2015 & Both chambers, 50 & 41.8 & $34.4^{\mathrm{a}}$ \\
Panama & 2014 & Unicameral, 50 & 19.3 & \\
Paraguay & 2013 & Both chambers, 20 & 15.0 & 20.0 \\
Peru & 2011 & Unicameral, 30 & 22.3 & \\
Uruguay & 2014 & Both chambers, 33 & 16.2 & 29.0 \\
\hline \hline
\end{tabular}

a2012 election results. Only the lower house renewed in 2015 .

Source: IPU 2015

cludes that states modernize gender relations by promoting programs (such as daycare crèches) that improve women's status while leaving intact patriarchal (and classist and racist) relations of power and exploitation (1990, 28-36). This theory also explains why quota researchers, in concluding that female lawmakers remain excluded from the most prestigious legislative posts, remain skeptical about quotas' effects on the distribution of political power (Franceschet and Piscopo 2008, 2014; Hawkesworth 2012; Miguel 2012; Schwindt-Bayer 2010). In a feminist institutionalist reading of this outcome (cf. Mackay et al. 2010), states modernize their outward appearance by including women but sanitize quotas by excluding women from the institutional spaces where "real" decisions are made.

On the other hand, poststructuralist scholars have moved away from straightforward analyses wherein a unitary state always subordinates women. Instead, poststructuralists conceive of "the state" as a multidimensional site of struggle, interdependence, and interaction (Randall 1998; Pringle and Watson 1998; Waylen 1998; Kantola 2006). The state is still one entity, but different spaces within the statedifferent institutions - can push policy change in new directions. Thus, the state "is not inherently patriarchal but was historically constructed as patriarchal in a political process whose outcome is open" (Kantola 2006, 12). Poststructuralists see feminist struggles as occurring within the state: normative discourses and institutional rules affect women's rights, but actors inside these spaces can reshape discourses and change rules (Kantola 2006, 12-14; Randall 1998, 198-203). Viewed through this theoretical lens, the state- as represented by one or many of its constitutive institutions - can become a feminist actor. 
To my knowledge, the poststructuralist theory of the state has not been explored with gender quotas as an empirical example. Yet such a lens illuminates how quotas' evolution has engaged feminist proponents and public officials in multiple sites of contestation, including autonomous state institutions (i.e., electoral agencies and high courts) and institutions guided by the decisions of current and past governments (i.e., legislatures, presidents' offices, and executive agencies). Furthermore, the poststructuralist recognition that women are simultaneously objects of state policy and agents of policy change takes on a unique twist in the case of quotas: as quotas evolve, women are not just improving their status, they are becoming the state (Hawkesworth 2012). Gender equality is actually enacted within (rather than simply enforced by) state institutions.

Quotas thus differ from other types of gender equality legislation in Latin America. In creating women's policy agencies, governments gave women some voice in policy debates, and in passing domestic violence or family law reforms, governments fulfilled their obligations, as stipulated in constitutions and international conventions, to end discrimination. In bringing women into legislatures (and executives and judiciaries), quotas also promote women's rights, but proactively rather than reactively. Quotas establish norms and regulations that guarantee equality not by erecting a neutral, nondiscriminatory legal framework, but by committing state institutions to positive actions that reconstitute those very institutions along feminist lines. Most gender equality reforms stipulate which laws state agents apply, but gender quotas establish laws—and consequently norms — about who the state agents must be. This process exemplifies the interdependent, iterative process wherein governments implement a singular reform and then women inside and outside the state contest and reshape this reform over time.

Following this reading, skeptics' dismay that quotas have not equalized the distribution of political power within institutions overlooks the larger significance of women becoming the state. Mansbridge (1999) supports positive actions for historically marginalized groups when these measures allow group members to participate in deliberation, which establishes the policies that serve the polity as a whole, and aggregation, which produces policy decisions in cases of conflicting interests (1999, 634). Quotas include women in deliberation and aggregation when they target legislatures, and they include women in arbitration-the impartial implementation and application of the laws-when applied to the executive and judicial branches. More important, however, quotas signal that women's participation is constitutive of these processes' democratic legitimacy. For example, the preamble of the 2010 Brasília Consensus, adopted by the UN Economic Commission for Latin America and the Caribbean at its 11th Regional Conference, states that gender balance in decisionmaking is "the key condition of democracy" (ECLAC 2010). Latin American states have begun using quotas to assert that gender-equal institutions undergird democracy, thereby behaving as gender equality activists. 


\section{STRENGTHENING QUOTA LAWS FOR NATIONAL LEGISLATURES}

Thirteen nations in Spanish- and Portuguese-speaking Latin America currently apply quota laws to national legislative elections (see table 1). ${ }^{1}$ Three more countries will apply quotas to their next elections: El Salvador, 30 percent beginning in 2015 (Law 307/2013); Chile, 40 percent between 2017 and 2029 (constitutional reform); and Nicaragua, 50 percent beginning in 2016 (Law 790/2012). Only Guatemala and Venezuela lack quota laws for national elections.

As table 2 demonstrates, most quota laws in Latin America have evolved over time. First-generation quotas mostly appeared in the 1990s and were subsequently reformed. Of the countries with quota laws effective for at least two election cycles (that is, excluding Colombia, Chile, El Salvador, Nicaragua, and Uruguay), eight reformed their original statutes at least once. Most commonly, reforms strengthened the quotas' initial threshold: only in Argentina and Paraguay has the initially established threshold remained unchanged (though Argentina did later mandate a 50 percent quota when district magnitude equals 2). ${ }^{2}$ In all other cases, Latin American states have shifted to parity. Thresholds initially set at 20,25, or 30 percent have increased to 50 percent, indicating a deepening consensus that any thresholds short of full equality are insufficient or even nonsensical (Archenti 2011; Franceschet and Piscopo 2013). Costa Rica, Ecuador, Bolivia, Mexico, and Panama practice parity, and for elections held from 2015 on, parity will apply in Honduras, Nicaragua, and Mexico.

Table 2 also illustrates how quota reforms strengthened implementation by requiring the rank-ordered placement of candidates on closed electoral lists and by establishing enforcement mechanisms (typically, electoral oversight bodies must certify party lists and impose sanctions for noncompliance). Viewing this strengthening process across the region as a whole reveals the myriad state institutions engaged in enforcing positive action. In Argentina, for instance, activist groups contested parties' noncompliance in court, creating accumulated jurisprudence that led to a hallmark 2000 presidential decree. This measure clarified the placement mandate, stipulated that female candidates who withdraw must be replaced with other female candidates, and extended the quota to the Senate (Marx et al. 2007). Elsewhere, female politicians lobbied for greater enforcement, leading to the establishment of placement mandates and threshold increases by electoral institutes (as in Costa Rica, via the electoral tribunal's Resolution 1863/1999) or the legislature (as in Mexico, via the 2008 electoral reform).

Across the region, these improvements also eliminated loopholes that were often exploited by political parties, which placed female candidates in the lowest list positions or replaced female nominees with male contenders. Constitutional assemblies also played significant roles: in Ecuador and Bolivia, constitutional delegates, themselves elected under quota laws, wrote the principles of gender balance into their nations' new constitutions. By contrast, presidents established parity in Nicaragua (Decree 54-2012) and Honduras (Decree 29/2010). 
Table 2. National-Level Legislative Quota Laws in Latin America

\begin{tabular}{|c|c|c|c|c|}
\hline & $\begin{array}{l}\text { Current } \\
\text { Quota Rule }\end{array}$ & $\begin{array}{c}\text { First } \\
\text { Adopted }\end{array}$ & $\begin{array}{c}\text { Key } \\
\text { Reforms }\end{array}$ & Brief Description (Year) \\
\hline Argentina & Both chambers, $30 \%$ & 1991 & 1993,2000 & $\begin{array}{l}\text { Placement mandate (1993, } \\
2000) \\
\text { Extension to upper chamber } \\
(2000)\end{array}$ \\
\hline Bolivia & Both chambers, $50 \%$ & 1997 & $2009 / 2010$ & $\begin{array}{l}\text { Threshold raised from } 30 \% \\
(2009 / 2010)\end{array}$ \\
\hline Brazil & Lower chamber, $30 \%$ & 1997 & 2000,2009 & $\begin{array}{l}\text { Threshold raised from } 25 \% \\
(2000) \\
\text { Quota positions must be filled, } \\
\text { not just reserved (2009) }\end{array}$ \\
\hline Chile & Both chambers, $40 \%$ & 2015 & & Applies 2017 through 2029 \\
\hline Colombia & Both chambers, $30 \%$ & 1998 & 2000,2011 & $\begin{array}{l}\text { Declared unconstitutional (2000) } \\
\text { Quota law reinstated (2011) }\end{array}$ \\
\hline Costa Rica & Unicameral, $50 \%$ & 1996 & 1999,2009 & $\begin{array}{l}\text { Placement mandate (1999) } \\
\text { Threshold raised from } 40 \% \\
(2009)\end{array}$ \\
\hline $\begin{array}{l}\text { Dominican } \\
\text { Republic }\end{array}$ & Lower chamber, 33\% & 1997 & 2000,2002 & $\begin{array}{l}\text { Threshold raised from } 25 \% \\
(2000) \\
\text { Senate exempted (2002) }\end{array}$ \\
\hline Ecuador & Unicameral, $50 \%$ & 1997 & $\begin{array}{c}2000 \\
2008 / 2009\end{array}$ & $\begin{array}{l}\text { Threshold raised from } 20 \% \\
\text { to } 30 \%(2000) \text { to } 50 \%(2008) \\
\text { Placement mandate }(2000) \\
\text { Extension to Senate } \\
(2008 / 2009)\end{array}$ \\
\hline El Salvador & Unicameral, 30\% & 2013 & & \\
\hline Honduras & Unicameral, $40 \%$ & 2000 & 2009,2012 & $\begin{array}{l}\text { Eliminated gradual threshold } \\
\text { increase; set at } 30 \%(2009) \\
\text { Threshold raised to } 40 \% \text {, } \\
\text { increasing to } 50 \% \text { in } 2016 \\
\text { (2012) }\end{array}$ \\
\hline Mexico & Both chambers, $50 \%$ & 1996 & $\begin{array}{c}2002, \\
2008,2014\end{array}$ & $\begin{array}{l}\text { Threshold raised from } 30 \% \\
\text { (2008) to } 50 \%(2014) \\
\text { Other loopholes closed (2014) }\end{array}$ \\
\hline Nicaragua & Unicameral, $50 \%$ & 2012 & & Applies beginning in 2016 \\
\hline Panama & Unicameral, $50 \%$ & 1997 & 2012 & $\begin{array}{l}\text { Threshold raised from } 30 \% \\
\text { (2012) }\end{array}$ \\
\hline Paraguay & Both chambers, $20 \%$ & 1996 & & \\
\hline Peru & Unicameral, 30\% & 1997 & 2000 & $\begin{array}{l}\text { Threshold raised from } 25 \% \\
(2000)\end{array}$ \\
\hline Uruguay & Both chambers, $33 \%$ & 2009 & & Applies to 2014 elections only \\
\hline Venezuela & Both chambers, $30 \%$ & 1997 & 2000 & Declared unconstitutional (2000) \\
\hline
\end{tabular}

Note: Entries in italics indicate dilution of quotas.

Sources: Crocker 2011; Quota Project; author's research. 
Thus, electoral institutions, court decisions, statutory reforms, and presidential decrees have all been leveraged to strengthen the region's quota laws. With the exception of the Dominican Republic — where a 2002 legislative reform exempted the Senate from the 1997 quota law-all cases of quota dilution (indicated by italics in table 2) have been followed by quota strengthening. In Honduras, the initial 2000 law established a 30 percent quota, to increase by five percentage points each election thereafter; the increase was never enforced, and the 2009 legislative reform fixed the quota at 30 percent. However, the 2012 legislative reform raised the threshold to 40 percent, which the president then increased to parity. ${ }^{3}$

Likewise, quotas "returned" in the two countries, Colombia and Venezuela, where they had been declared unconstitutional in 2000. In Venezuela, despite the Supreme Court's ruling, the independent electoral tribunal demanded paritymeaning the alternation of men's and women's names on the electoral lists-for the 2005 and 2008 national elections. Explaining this decision, Jhannet Madriz Soltillo $(2012,335)$ refers to her commitment, as the first female member of the tribunal, to promoting women's political rights. In Colombia, the constitutional court had overturned quotas on the grounds that such laws interfered with party autonomy (Corte Constitucional de Colombia 2000). Legislative Act 1 of 2009 reformed the Colombian Constitution, redefining political parties as essential components of the democratic state: political parties must organize themselves according to the same principles of gender equality as the state itself. Reformulating political parties made Colombia's 2011 quota law possible.

Thus, feminist actors in public office and in civil society have successfully pressured different state institutions to strengthen quota laws. The process undertaken by late-adopting countries, such as Colombia, typifies how the legal frameworks of positive action become institutionalized. First, equal rights laws or constitutions establish that democratic institutions-from legislatures to parties—are formulated along the lines of gender equality; then, statutes or decrees implement quotas. In another example, the 2008 equal opportunity law in Nicaragua mandated that political parties guarantee the "equal participation" of men and women in internal decisionmaking positions and that the state establish a "proportional percentage" of women and men for elected and appointed positions at all levels of government (Presidente de la República de Nicaragua 2008). The president's 2010 decree clarified that these phrases meant 50-50 representation and instructed all state institutions to "carry out" this requirement (Presidente de la República de Nicaragua 2010). Consequently, the 2012 electoral reform established parity for Nicaragua's legislative assembly. Likewise, members of the electoral tribunal in the Dominican Republic have demanded that new electoral reforms include parity because, in their view, the 2010 Constitution binds the state to ensuring men's and women's equivalent participation (Noticias Sin 2014). Quota proponents are thus demandingand gradually winning — reforms that reorganize the state along gender-equal lines. 


\section{QUOTA EXPANSION: RETHINKING THE SKePTICAL NARRATIVE}

Quotas' strengthening reveals that multiple state arenas enforce positive action. Yet many analyses have concluded that quotas constitute a cynical or symbolic government strategy; that is, elites accept quotas because they can neutralize their effects (Sagot 2010; Tinker 2004). Indeed, as discussed above, initial quota laws were weak on enforcement and strong on loopholes. First-generation quotas gave political parties and chief executives the ability to gain electoral support from women while evading the measures in actual practice (Baldez 2004; Jaquette 1997). In the words of Htun and Jones, initial quota laws constituted mere "lip service" by political elites to female activists $(2002,15)$. Furthermore, scholars have concluded that quotas, even when numerically successful, fail to overturn the entrenched legislative sexism that inhibits women's ability to wield "real" policy power (Franceschet and Piscopo 2008, 2014; Marx et al. 2009; Miguel 2012). Both findings seemingly support the idea of a patriarchal state, one that sanitizes improvements to women's status and leaves preexisting structures of marginalization intact.

Yet first-generation quota laws also paved the way for their own strengthening. At least some women "became" the state, and these proponents could leverage their inside access to improve second- and third-generation quota laws. In a recent example from Honduras, female legislators, party members, candidates, and activists successfully lobbied the electoral reform commission to increase the quota and to mandate parties' expenditures on women's training and campaigns (El Heraldo 2012). The differentiated, poststructuralist state thus allows female proponents to "venue shop" for those state institutions most likely to support quota reforms. This process exemplifies states' behaving as gender equality activists: quotas are expanded via a process wherein state institutions go beyond minimum compliance and make quotas permanent and more heavily regulated.

\section{Making Quotas Permanent Through Jurisprudence}

Quota proponents have discovered that state institutions, especially high courts, are disposed to expand rather than merely enforce quota laws. Recent developments from Mexico prove illustrative. In 2011, in preparation for the 2012 legislative elections, Mexico's electoral oversight body (the Instituto Federal Electoral, or IFE) ordered that political parties must observe the legal 40 percent quota, as well as any internal quotas listed in their statutes. ${ }^{4}$ This decision bound those parties that had voluntarily adopted 50 percent quotas to their commitments (Gastélum Bajo 2013). Yet the IFE refused to overturn a controversial loophole in Mexico's quota law: an exemption for candidates selected via internal party primaries. Ten female politicians representing several Mexican parties, having unsuccessfully petitioned the IFE to eliminate the loophole, brought suit in the nation's federal electoral court - the highest judicial body empowered to 
rule on matters of electoral law. These proponents received even more than they anticipated (Feminist activist 2013).

In its ruling, the court both struck the primary exemption and eliminated a longstanding practice wherein female titleholders would, on election, yield their posts to their male substitutes (Tribunal Electoral 2011). ${ }^{5}$ These so-called Juanitas had generated outrage following the 2009 congressional elections, when 16 female deputies-elect resigned. Politicians and journalists alike trumpeted their disapproval, denouncing the Juanitas as perpetuating "electoral fraud" (Female legislator, PAN 2009; Female former legislator, PRD 2009). Nevertheless, an amendment to Mexico's quota law that would mandate same-sex candidate pairings died in the Senate (Excelsior 2011).

Into this vacuum stepped the federal electoral court, ruling that women's political rights were human rights: since international and domestic law afforded human rights the widest possible guarantees, the court concluded that the quota law must apply "without any exception" (Tribunal Electoral 2011). Judge María del Carmen Alanis characterized the ruling as "the court's guarantee that the venues where public life unfolds are free from discrimination" $(2013,95)$. Thus, in a subsequent decision, the court rejected arguments that moving male candidates down electoral lists constituted discrimination, a decision that affirmed the constitutionality of electoral slates that alternate men's and women's names (Tribunal Electoral 2013). These two rulings together established the groundwork for parity, leading President Enrique Peña Nieto to introduce a parity bill in October 2013. The congress adopted parity two months later as part of broader constitutional reforms.

On the one hand, this "above and beyond" compliance appears surprising. Elites intended quotas as lip service, and poststructuralists recognize that state institutions like the IFE and the Mexican Senate may resist feminist outcomes (Kantola 2006). On the other hand, poststructuralists show that other state institutions may embrace feminist objectives. High courts particularly have found themselves bound to respecting states' prior commitments to positive action and gender equality.

All Latin American states have signed international conventions on gender equality, and all save Argentina have statutory or executive branch gender equality plans currently in place. Moreover, national constitutions encode the language of positive action. ${ }^{6}$ For example, the 1992 Constitution in Paraguay binds the state to "promote conditions and implement appropriate measures to make equality real and effective, smoothing the obstacles that impede or obstruct equality and facilitating the participation of women in all aspects of public life" (Article 48). Similarly, the 1994 Argentine Constitution stipulates that Congress may "legislate and promote positive measures guaranteeing true equal opportunities and treatment" (Section 23) and that "the equality of opportunities for men and women to elective and political party positions shall be guaranteed by means of positive actions in the regulation of political parties and in the electoral system" (Section 37). The 2009 Bolivian Constitution recognizes a "participatory, representative, and communitarian democracy with equivalence of conditions between women and men" (Article 11). Latin American constitutions include quota laws explicitly (Bolivia, Ecuador, and 
Mexico), make quota laws permissible (Colombia), or affirm the state's obligation to promote women's access to political office (Argentina, Costa Rica, the Dominican Republic, Nicaragua, Paraguay, and Peru).

Thus actors within state institutions leverage the gender equality principles established in treaties, laws, or constitutions to expand quotas. Costa Rica's experience also illustrates this point. First, the 2007-12 National Policy on Gender Equality and Equity, adopted by the executive branch, recognized the importance of gender balance, a goal beyond the 40 percent quota in place at the time. Second, a 2008 Constitutional Court decision invalidated party statutes that calculated "electable positions" in ways that relegated women to the bottom list positions. The court concluded that "positive action is clearly and fully justified when the legal corrective measures will attain true equity between men and women" (Sala Constitucional de la Corte Suprema de Justicia, 2008). In Costa Rica, as in Mexico, these high court decisions, which initially addressed specific quota loopholes, established broader claims that intertwined gender equality, women's inclusion, and democratic legitimacy. In these contexts, parity became the only legally permissible alternative.

Quotas therefore differ significantly from legislation that establishes states' negative obligations to protect women from harm. When officials must choose between ignoring or enforcing quotas, they find themselves bound by the normative and legal commitments to gender equality that are embedded across state institutions. Quota expansion-the process wherein women become the state-becomes inevitable.

\section{Enhancing Women's Preparedness Through Regulation}

Quota skeptics also use the persistence of sexist practices to illustrate the patriarchal state's sanitization or co-optation of the measures. As Jiménez Polanco observes, in the Dominican Republic, male party elites outwardly celebrate quotas' ability to make them appear modern and democratic but inwardly "fear that a real increase in the number of women occupying political posts might threaten their power" (2011, 141). Party elites thus attempt to neutralize the threat posed by women elected under quotas ("quota women"). Female legislators are assigned to low-prestige policy areas or committees (Miguel 2012; Heath et al. 2005; Schwindt-Bayer 2010). Feminist legislators, in particular, are silenced (Franceschet and Piscopo 2008), threatened (Htun and Ossa 2013, 11), denied re-election (Alcocer 2013, 74), or not nominated (Sagot 2010).

Skeptics also point out that even women with qualifications or positions of power and influence may remain uninterested in gender equality. Mexican feminist Marta Lamas (2000) has cautioned that "women's bodies do not guarantee gender consciousness." Critics further suggest that elite women are unrepresentative or unfeminist and therefore unlikely to challenge the status quo (Costa Benavides 2003; Franceschet et al. 2012). Sagot's diagnosis of the Costa Rican case captures this disillusion with quota women: "The passing of the quota legislation has also 
meant the arrival into power of many conservative women, closely connected to political and economic elites, who do not have any progressive agenda" $(2010,29)$. Essentially, skeptics fret that quotas have not borne out the promise made by Argentine proponents: "with few women in politics, women change; with many women in politics, politics changes" (Marx et al. 2007, 67).

Skeptics correctly note that female legislators cannot always translate their increased presence into deeper policy gains, especially given the variation in quota women's backgrounds and feminist leanings. Yet focusing on these shortcomings risks overlooking how the state has acted to improve women's professional development. Female legislators, themselves often elected under first-generation quotas, have lobbied for measures that would counter parties' most frequent objections to quotas: that few qualified women exist. Their success appears in the recently adopted "party rules" in nine Latin American countries: Brazil, Chile, Colombia, Costa Rica, Ecuador, Honduras, Mexico, Panama, and Uruguay. These regulations, incorporated into the quota laws, extend beyond mere enforcement: they expand quotas' reach by requiring that political parties set gender targets for internal primaries and party directorates and allocate resources to female party members (Ferreira Rubio 2012).

As such, party rules promote women's leadership and thus improve the quality of the candidate pool, though their exact provisions vary. Some are carrots: parties receive additional state funding as a bonus for nominating women (Colombia) or electing them (Chile). The Chilean measure "encourages parties to run female candidates in territories where they have real possibilities of winning" (Presidenta de la República 2014). Most party rules, however, are sticks. Political parties must establish specific provisions for gender equality or gender quotas in their charters (Costa Rica and Mexico); apply the legal quota to internal elections, either for party leaders (Costa Rica, Honduras, and Uruguay) or for candidates and party leaders (Ecuador); and allocate certain percentages of their total funding to programs that recruit, train, or otherwise cultivate female aspirants or candidates (Brazil, 5 percent; Colombia, 15 percent; Costa Rica, no specific amount; Honduras, 10 percent; Mexico, 3 percent; and Panama, 5 percent). ${ }^{7}$ The Brazilian provision uniquely requires that 10 percent of parties' state-granted, noncampaign-related television time be used to promote female leadership.

These regulations - all adopted in the past six years - are neither irrelevant nor symbolic addenda to quota legislation. They constitute highly significant interventions into the private, associational life of political parties, placing conditions on how parties conduct business, choose leaders, and allocate resources. These interventions-like the Colombian constitutional reform-extend the state's regulatory authority over parties, making parties additional sites where feminist objectives must be enacted. Furthermore, these regulations permanently alter the rules of the game: whereas Uruguay's quota law applied the candidate quota to the 2014 elections, the party rule applying quotas for internal elections never expires. Surprisingly, rightleaning elites accept and even advocate for party rules because they view the measures as preserving meritocracy in candidate selection. As a female leader of Mexico's 
conservative PAN commented, "If we are going to have to nominate women, let's make them ready" (García García 2013).

Moreover, state institutions act as feminists by not just adopting but enforcing party rules. The Mexican experience again proves illustrative. After the 2008 quota reform required that parties expend 2 percent of their annual budget on women's leadership training, female party members and female legislators-many of whom had initiated the earlier court case-demanded that the IFE establish a clear regulatory process to monitor these expenditures (Chief IFE Accountant 2013). Female activists and IFE regulators worked together over 2010 and 2011 to establish the Plan Anual de Trabajo (Annual Work Plan). Since 2012, political parties must submit a gender spending plan each February and an expense report each December. This plan must focus on programming and must go beyond the percentage (currently set at 3) required by law: "the remaining 98 percent of the budget must also show gender awareness and gender programming" (Chief IFE Accountant 2013). Improved monitoring by the electoral institute has led to demonstrable results (Chief IFE Accountant 2013). For instance, over 2012 and 2013, Mexico's PRI claimed to have trained twenty thousand women through in-person and online programs, 60 percent of whom attained elected positions at the municipal or state level (Party director PRI 2013).

Therefore, evidence from quota expansion does not support skeptics' assessments of quotas as co-opted and sanitized by the state. Sagot asserts that "the women's movement's transforming approaches [quotas] are then 'recycled' by the State and returned to society as socially acceptable laws and policies that do not represent a real threat to the establishment" $(2010,29)$. Yet state institutions-especially courts and electoral institutes—have responded favorably to feminist advocacy: they have established jurisprudence and passed and enforced regulations that make quotas - and the underlying norms of positive action-permanent features of how parties "do business." By compelling parties to invest in women's professional development, party rules mitigate the nomination of token or unqualified candidates and help women position themselves as more effective leaders and policymakers.

\section{QUOTA DIFFUSION AND ACTIVIST STATES}

The skeptical narrative of gender quota laws in Latin America conceptualizes quotas as a game in which elites leverage the benefits of modernity without paying the costs of change. Seeing them as such, skeptics would not be surprised that gender quotas have diffused beyond the national legislature to subnational assemblies, executive cabinets, the judiciary, and voluntary organizations: why wouldn't strategic elites continue to seek symbolic benefits by expanding quotas' scope? The alternative narrative advocated in this article, however, views states as gender equality activists: the poststructuralist state allows for some state institutions to act in pursuit of feminist objectives. Quota diffusion further supports this narrative because even if cynicism motivates elite support for nonlegislative quotas in the 
Table 3. Legislative Quota Laws for the Subnational Level in Latin America

\begin{tabular}{llll}
\hline \hline & Current Quota Rule & First Adopted & Reformed \\
\hline Argentina & Varies by province & & \\
Bolivia & Departmental, municipal, 50\% & 2009 & 2010 \\
Brazil & Municipal, state, 30\% & 1995 & 1997,2000 \\
Colombia & Departmental, 30\% & 2011 & \\
Costa Rica & Municipal, 50\% & 1996 & 2009 \\
Dominican Republic & Municipal, 33\% & 1997 & 2000 \\
Ecuador & Municipal, 50\% & 2000 & 2008,2009 \\
El Salvador & Municipal, 30\% & 2013 & \\
Honduras & Regional, municipal, 30\% & 2009 & \\
Nicaragua & Municipal, 50\% & 2012 & \\
Mexico & State, 50\% & 2014 & \\
Paraguay & Departmental, 20\% & 1996 & \\
Peru & Regional, municipal, 30\% & 1998 & \\
Uruguay & Departmental, 33\% & 2009 & \\
Venezuela & Regional, municipal, 50\% & 2008 & \\
& & & \\
\hline \hline
\end{tabular}

Source: Crocker 2011; author's research

short run, these measures will ultimately reconfigure the gendered distribution of policymaking power in the long run.

As evidence for diffusion, 15 Latin American countries apply quotas to subnational legislative elections, as shown in table 3. Eleven adopted subnational rules in the same statute that authorized the national-level legislative quota (Colombia, El Salvador, Nicaragua, Paraguay, Peru, and Uruguay) or in a subsequent reform (Bolivia, Costa Rica, the Dominican Republic, Ecuador, and Honduras). National and subnational legislative quotas generally appear together, though Venezuela applies a subnational quota without a national quota and the Argentine provinces manage their own elections (though all 24 provinces have quotas). The Mexican states are similarly autonomous, though the electoral court recently decreed that states must implement the constitution's human rights norms (Tribunal Electoral 2014). Since these norms include parity, Mexican states will be unable to appeal to customary law (usos y costumbres) in order to avoid parity - again illustrating how one state institution may force others to practice gender equality. Though subnational quotas vary in their effectiveness in the region as a whole, they do alter officeholding patterns by bringing unprecedented numbers of women into local governance. As such, they work in tandem with party rules to enhance female candidates' preparedness.

While subnational quotas in Latin America have been well studied (Archenti and Tula 2011; Zetterberg 2011; dos Santos 2012; Barnes 2012), quotas' application outside the legislative branch has received less documentation and analysis. In Latin America, nonlegislative quotas have extended positive action such that women truly become "the state": quotas have extended state interference to both public and private institutions, from supreme courts to civil society organizations. 
The first type of nonlegislative quotas are executive quotas, currently found in Bolivia, Colombia, Costa Rica, the Dominican Republic, Ecuador, Honduras, and Nicaragua. In Costa Rica, the quota applies to one of the two vice presidential positions; and in the Dominican Republic, Honduras, and Nicaragua, party lists for municipal executive - which contain a mayor and a vice mayor - must contain at least one female name. Yet parties' history of minimalist quota compliance suggests that parties would sanitize executive quotas by appointing women to the vice executive positions. However, female chief executives, even if fulfilling honorary or nonpolicy roles, still change the outward face of the executive branch. Studies of quotas for village council leaders in India, for instance, found that the mere "exposure to female leaders" eroded negative, sexist perceptions about women who speak in public or who work outside the home (Beaman et al. 2012).

Thus, executive quotas continue to reshape norms about who should "be" the state. This objective appears even more strongly when executive quotas apply to national cabinets and the bureaucracy. In Colombia, the "highest positions" in the executive branch at all government levels must comprise 30 percent women. The mayor of the autonomous district of Mexico City recently decreed that the entire public administration must implement parity by 2019, which includes gender balance among the popularly elected officials who administer the city's 16 subdistricts (Ciudad de México 2014). Bolivia and Ecuador possess the strongest executive quotas, as their constitutions stipulate men's and women's equal representation in the executive at all levels, including the electoral oversight body and the administrations of the autonomous indigenous communities.

For Bolivia and Ecuador, executive quotas resulted from constitutional assemblies' reconstitution of the country along the principles of parity, which occurred following the ascendance of indigenous leaders and parties in the 2000s. Costa Rica, Honduras, Panama, Nicaragua, and Mexico have established parity for the legislature, but Ecuador and Bolivia have actually established parity governments. The 2008 Ecuadorian Constitution specifies that all citizens have the right to hold and discharge public office in a system that "guarantees their participation on the basis of the criteria of gender equity and parity" (Article 61.7) and decrees the state's positive obligation to foster a "parity approach" or "parity membership" in composing each government branch (see, e.g., Articles 108, 116, 157, and 176). The 2009 Bolivian Constitution, in recognizing the "equivalence of conditions" between men and women in the practice of democracy (Article 11), anticipated the 2010 political reforms. These five laws, passed together, collectively guarantee parity in the election and designation of all state agents (Coordinadora de la Mujer 2010).

In this way, Presidents Evo Morales (Bolivia) and Rafael Correa (Ecuador) have sought parity cabinets and parity judiciaries. Ecuador had previously adopted a judicial quota in 1997, decreeing that the Supreme Court be composed of 25 percent women and that all nomination slates for the lower-level courts must contain 20 percent women. Now, under both countries' new constitutions, parity applies across all judicial institutions, from the highest courts to the administrative service. 
Latin American countries' unfolding commitment to parity government broadens the number and type of state institutions in which feminist struggles take place. Actors now view parity "as an unavoidable tool to obtain gender equality," one "founded [on the principle] of equal rights" (Archenti 2011, 22). Chief executives, constitutional assemblies, and legislatures have built from normative commitments and regulatory frameworks established by previous generations' quota laws and equal rights norms. Actors in these institutions now see equality-and thus democratic legitimacy —as hinging on women's participation in the deliberative, aggregative, and arbitrative aspects of policymaking.

Moreover, as with party regulations, nonlegislative quota laws also impose positive action on organizations typically beyond their reach. Private associations have become subject to state regulation via civil society quotas, which establish minimum levels of women's representation on the boards of voluntary organizations. These groups are political insofar as they participate in electoral campaigns and policy debates, though their leadership structures were previously private and exempt from state interference. Yet once voluntary organizations-like political parties-became viewed as interlocutors of democratic dialogue and as training grounds for political office, their governance structures became a target of state interference. For example, Argentina has applied a 30 percent quota for trade union directorates since 2003 (Law 25674). The legislator who wrote the proposal wished to democratize unions' internal decisionmaking practices by encouraging women, who composed much of the organizations' rank and file, to seek leadership positions (Female legislator, Argentina 2009).

Costa Rica's 2011 civil society quota (Law 8901) is even more comprehensive: the measure imposes parity on the boards of all voluntary organizations, from trade unions to charity groups to sports governing bodies. The nation's constitutional court recently upheld the measure, affirming the state's obligation "to guarantee the incorporation of women in decisionmaking spaces that have been historically male, and thus contribute to women's full citizenship" (Defensoría de los Habitantes 2014). Civil society quotas-like legislative quotas—are backed by jurisprudence that recognizes the state's active role in politically empowering women.

Indeed, this role shows little sign of diminishing. For example, a 2003 executive decree issued by then-Argentine president Néstor Kirchner stipulated that "gender diversity" must be considered by presidents selecting Supreme Court judges (Presidente de la Nación de Argentina 2003). The Peruvian Congress debated a 30 percent judicial quota in 2009 and a 30 percent executive branch quota in 2010 (Demus 2009). The Nicaraguan legislature considered a 50 percent quota for the cabinet and the diplomatic corps in 2012 (Nuevo Diario 2012).

Presidents have also pursued parity informally, with Michelle Bachelet in Chile, Daniel Ortega in Nicaragua, and Ollanta Humala in Peru seeking gender balance in their cabinets (Barnes and Jones 2011, 109; Franceschet and Thomas 2013; La Repuiblica 2013). In 2013, Mexico's IFE announced that 96 positions in the organization's civil service would be reserved for women. The decision was challenged in—but upheld by—the federal electoral court. An IFE senior official justified the 
policy, asking rhetorically, "How can we enforce gender equality if we cannot demonstrate that we take it seriously ourselves?" (Chief IFE Accountant 2013). The Brazilian legislature considered a 40 percent quota for women on corporate boards in 2011 (Paul Hastings 2011).

Taken together, quotas represent an ever-expanding category of policies through which actors leverage state institutions, from high courts to legislatures, to follow through on their positive obligations to include women in governance. Quotas' diffusion beyond legislatures signals an emerging trend of "states' willingness to use coercive measures to ensure women's access to arenas of political and social power" (Franceschet and Piscopo 2013, 310, emphasis added). In this way, the poststructuralist state becomes a site for women's inclusion and feminist change.

\section{Conclusions}

Gender quotas incorporate women into the core functions of democracy: deliberation, aggregation, and arbitration. While quotas may not immediately transform the patriarchal attitudes and conservative policies that sustain sexual inequality, their evolution - their strengthening, expansion, and diffusion — has been demanded by the state, in order to reform the state. Though different state institutions drive quota improvements at different moments, these arenas — which represent the larger state apparatus-deepen and enforce feminist objectives. This process unfolds in an iterative fashion: as women become the state, they demand further quota improvements from within, and positive action spreads to an ever-expanding set of institutions, including traditionally private associations, such as trade unions and civil society organizations. Though the configuration of actors and arenas varies across cases, the regional view reveals that Latin American states are using their coercive powers to bring women into governance. In contemporary Latin America, women's inclusion is not a negative right backed by neutral nondiscrimination laws but a positive right guaranteed by state action.

This reading of quotas thus departs from scholarship focused on quotas' adoption or their numerical effectiveness. This study argues that the decades-long process of quota strengthening, expansion, and diffusion demonstrates the measures' potency, not weakness. The regional trend has been to consistently improve quotas because, through a combination of broader equality commitments and first-generation quota laws, Latin American states have tied their own hands. At any given time, elites have strong incentives to cheat the quota, but the broader institutional setting-discourses, statutes, and jurisprudence—makes quota commitments credible and enforceable. This institutional setting gives quota proponents normative and legal recourses and binds the region's political elites into regularizing positive action.

This conclusion raises two directions for future research. First, this article has broadly conceptualized states as gender equality activists, but this idea merits further refinement. In-depth case studies of nonlegislative quotas might further explore the iterative relationship between the institutional setting and quota proponents: do certain arenas (e.g., constitutional courts and electoral tribunals) act more consistently 
than others in specific cases? In general, more investigation and documentation of patterns is needed: for example, why parity in the Andes and Central America but not the Southern Cone? Why the activism of the electoral court in Mexico versus the legislature elsewhere?

Second, additional studies should critically evaluate the expectations and outcomes associated with women's "becoming" nonlegislative institutions. This study has argued that diffusion disproves claims that Latin American states sanitize gender equality reforms, but scholars have not examined whether "quota women" in executive branches, judiciaries, and private associations experience the same marginalization as quota women in legislatures. A better grasp of the adoption, enforcement, and consequences of nonlegislative quotas in Latin America will provide additional insights into whether states' gender equality activism in terms of inclusion brings results in terms of policy outcomes.

\section{NoTES}

I am grateful to Caroline Beer, Susan Franceschet, Magda Hinojosa, Mala Htun, Diana Z. O’Brien, Christina Xydias, members of the Gender and Feminist Studies Section of the Latin American Studies Association, three anonymous reviewers, and the editors for their invaluable feedback on this manuscript. I also thank Malena Ernani for her research assistance.

1. The Panamanian, Ecuadorian, and Paraguayan laws apply to internal primaries, not the general election, although in Ecuador and Paraguay final candidate lists must meet the quota. The Uruguayan quota applied only to the 2014 elections.

2. This provision also applies to parties or coalitions contesting their first elections.

3. Honduras does not use identifying numbers for its laws. The quota reforms appeared as revisions to Article 105 of the electoral code, adopted on November 29, 2009 and revised on April 20, 2012.

4. In December 2013, after the events described in this article, IFE became INE (Instituto Nacional Electoral).

5. A practice also noted in Bolivia (Htun and Ossa 2013).

6. All constitutions may be downloaded from the Political Database of the Americas, http://pdba.georgetown.edu/Constitutions/constudies.html.

7. The Colombian rule applies to women, youth, and minorities; the Honduran rule to women and youth.

\section{REFERENCES}

Alanis, María del Carmen. 2013. Justicia electoral con enfoque de género. In Cuota de género: una sentencia histórica, ed. Jorge Alcocer. Mexico City: Nuevo Horizonte. 75-97.

Alcocer, Jorge. 2013. Sentencia histórica. In Cuota de género: una sentencia histórica, ed. Alcocer. Mexico City: Nuevo Horizonte. 61-74.

Alvarez, Sonia E. 1990. Engendering Democracy in Brazil. Princeton: Princeton University Press.

Archenti, Nélida. 2011. La paridad política en América Latina y el Caribe. Percepciones y opiniones de los líderes de la región. Santiago de Chile: CEPAL, División de Asuntos de Género. 
Archenti, Nélida, and María Inés Tula. 2011. Candidate Selection as Political Barriers for Gender Quotas: The Case of Argentina at Subnational Levels. In Crocker 2011.

Baldez, Lisa. 2004. Elected Bodies: The Gender Quota Law for Legislative Candidates in Mexico. Legislative Studies Quarterly 24, 2: 231-58.

- 2007. Primaries vs. Quotas: Gender and Candidate Nominations in Mexico, 2003. Latin American Politics and Society 49, 3 (Fall): 69-96.

Barnes, Tiffany D. 2012. Gender and Legislative Preferences: Evidence from the Argentine Provinces. Politics and Gender 8: 483-507.

Barnes, Tiffany D., and Mark P. Jones. 2011. Latin America. In Women and Executive Power, ed. Manon Tremblay and Gretchen Bauer. New York: Routledge. 105-21.

Beaman, Lori, Rohini Pande, and Alexandra Cirone. 2012. Politics as a Male Domain and Empowerment in India. In Franceschet et al. 2012. 208-26.

Bush, Sarah Sunn. 2011. International Politics and the Spread of Quotas for Women in Legislatures. International Organization 65, 1: 103-37.

Chief IFE Accountant. 2013. Author interview. Mexico City, December 11.

Ciudad de México. 2014. Decreto por el que se reforma diversas disposiciones de la Ley Orgánica de la Administración Pública del Distrito Federal. Gaceta Oficial del Distrito Federal No. 1839, April 15.

Coordinadora de la Mujer (Bolivia). 2010. Balance de 5 leyes promulgadas. La Paz: Observatorio de Género, Coordinadora de la Mujer.

Corte Constitucional de Colombia. 2000. Sentencia C-371/00. Bogotá.

Corte Suprema de Justicia (Costa Rica). Sala Constitucional. 2008. Resolución 2008009582. San José.

Costa Benavides, Jimena. 2003. Women's Political Participation in Bolivia: Progress and Obstacles. Paper presented at the conference "Implementation of Quotas: Latin American Experiences." International IDEA, Lima, February 23-24.

Crocker, Adriana, ed. 2011. Diffusion of Gender Quotas in Latin America and Beyond. New York: Peter Lang.

Dahlerup, Drude, and Lenita Freidenvall. 2005. Quotas as a "Fast Track" to Equal Representation for Women. International Feminist Journal of Politics 7, 1: 26-48.

Defensoría de los Habitantes. Costa Rica avanza en materia de derechos humanos al reconocer paridad de género en juntas directivas. Press Release. April 8. San José: Defensoría de los Habitantes.

Demus. 2009. Justicia de género: acciones afirmativas en el sistema de justicia. Lima: Demus: Estudio para la Defensa de los Derechos de la Mujer. www.Demus.org.pe

Dos Santos, Pedro G. 2012. Gendering Representation: Parties, Institutions, and the UnderRepresentation of Women in Brazil's State Legislatures. Ph.D. diss., University of Kansas.

Economic Commission on Latin America and the Caribbean (ECLAC). 2010. Brasília Consensus. Presented at the Eleventh Regional Conference on Women in Latin America and the Caribbean, Brasília, July 13-16.

Excelsior (Mexico City). 2011. Senado decide conserver a juanitas; la spotización persistirá. April 30.

Female former legislator, PRD. 2009. Author interview. Mexico City, December 8.

Female legislator, Argentina. 2009. Author interview. Buenos Aires, April 21.

Female legislator, PAN. 2009. Author interview. Mexico City, December 8.

Feminist activist who helped coordinate lawsuit. 2013. Author interview. Mexico City, December 12. 
Ferreira Rubio, Delia M. 2012. Financimiento político, género, y equidad en la competencia electoral. Revista Andamios 7-8: 78-86.

Franceschet, Susan. 2010. Explaining Domestic Violence Policy Outcomes in Chile and Argentina. Latin American Politics and Society 52, 3 (Fall): 1-29.

Franceschet, Susan, and Gwynn Thomas. 2013. Changing Representational Norms in the Executive Branch: Parity Cabinets in Chile and Spain. Paper presented at the European Conference on Politics and Gender, Barcelona, March 21-23.

Franceschet, Susan, and Jennifer M. Piscopo. 2008. Quotas and Women's Substantive Representation: Lessons from Argentina. Politics and Gender 4, 3: 393-425.

2013. Equality, Democracy, and the Broadening and Deepening of Gender Quotas. Politics and Gender 9, 3: 310-16.

- 2014. Sustaining Gendered Practices? Power and Elite Networks in Argentina. Comparative Political Studies 47, 1: 86-111.

Franceschet, Susan, Mona Lena Krook, and Jennifer M. Piscopo, eds. 2012. The Impact of Gender Quotas. New York: Oxford University Press.

García García, Carmen María de Fátima. 2013. Comments at event "Towards Parity in Mexico," National Archives, Mexico City, September 24.

Gastélum Bajo, Diva Hadamira. 2013. Comments at event "Towards Parity in Mexico," National Archives, Mexico City, September 24.

Hawkesworth, Mary. 2012. Political Worlds of Women: Activism, Advocacy, and Governance in the Twenty-First Century. Boulder: Westview Press.

Heath, Roseanna, Leslie Schwindt-Bayer, and Michelle Taylor-Robinson. 2005. Women on the Sidelines: Women's Representation on Committees in Latin American Legislatures. American Journal of Political Science 49, 2: 420-36.

El Heraldo (Tegucigalpa). 2012. Mujeres quieren la mitad de la cuota electoral y de la deuda política. January 19.

Hinojosa, Magda. 2012. Selecting Women, Electing Women: Political Representation and Candidate Selection in Latin America. Philadelphia: Temple University Press.

Htun, Mala. 2003. Sex and the State: Abortion, Divorce, and the Family Under Latin American Dictatorships and Democracies. Cambridge: Cambridge University Press.

Htun, Mala, and Juan Pablo Ossa. 2013. Political Inclusion of Marginalized Groups: Indigenous Reservations and Gender Parity in Bolivia. Politics, Groups, and Identities 1, 1: 4-25.

Htun, Mala, and Mark P. Jones. 2002. Electoral Quotas and Women's Leadership in Latin America. In Gender and the Politics of Rights and Democracy in Latin America, ed. Nikki Craske and Maxine Molyneux. New York: Palgrave. 32-56.

Inter-Parliamentary Union (IPU). 2015. Women in National Parliaments. Database. http://www.ipu.org/wmn-e/classif.htm. Accessed July 19, 2015.

Jaquette, Jane S. 1997. Women in Power: From Tokenism to Critical Mass. Foreign Policy 108: 23-37.

Jaquette, Jane S., ed. 2009. Feminist Agendas and Democracy in Latin America. Durham: Duke University Press.

Jiménez Polanco, Jacqueline. 2011. Women's Quotas in the Dominican Republic: Advances and Detractions. In Crocker 2011. 130-50.

Jones, Mark P. 1996. Increasing Women's Representation via Gender Quotas: The Argentine Ley de Cupos. Women and Politics 16, 4: 75-98.

- 1998. Gender Quotas, Electoral Laws, and the Election of Women: Lessons from the Argentine Provinces. Comparative Political Studies 31, 1: 3-21. 
2004. Quota Legislation and the Election of Women: Learning from the Costa Rican Experience. Journal of Politics 66, 4: 1203-23.

- 2009. Gender Quota Laws and the Election of Women: Evidence from the Latin American Vanguard. Comparative Political Studies 42, 1: 56-81.

Kantola, Johanna. 2006. Feminists Theorize the State. New York: Palgrave MacMillan.

Krook, Mona Lena. 2009. Quotas for Women in Politics: Gender and Candidate Selection Reform Worldwide. New York: Oxford University Press.

Lamas, Marta. 2000. Un cuerpo de mujer no garantiza un pensamiento de mujer. Cimac Noticias, October 31. http://www.cimac.org.mx/noticias/00oct/00103106.html. Accessed January 23, 2015.

Mackay, Fiona, Meryl Kenny, and Louise Chappell. 2010. New Institutionalism Through a Gender Lens: Towards a Feminist Institutionalism? International Political Science Review 31, 5: 563-88.

Madriz Sotillo, Jhannett. 2012. Visibilización de la mujer en la República Bolivariana de Venezuela. Derecho Electoral (Venezuela) 13 (enero-junio): 318-35.

Mansbridge, Jane. 1999. Should Blacks Represent Blacks and Women Represent Women? A Contingent Yes. Journal of Politics 61, 3: 628-57.

Marx, Jutta, Jutta Borner, and Mariana Caminotti. 2007. Los cupos de género y politica en Argentina y Brasil. Buenos Aires: Siglo XXI.

$$
2009 .
$$

Miguel, Luis Felipe. 2012. Policy Priorities and Women's Double Bind in Brazil. In Franceschet et al. 2012. 103-18.

Noticias Sin (Santo Domingo). 2014. Defienden paridad de la mujer en las candidaturas electorales. April 3.

El Nuevo Diario (Managua). 2012. Oposición nicaragüense propone cuota de 50\% de mujeres en cargos de poder. March 27.

Party director, PRI. 2013. Author interview. Mexico City, December 19.

Paul Hastings. 2011. Breaking the Glass Ceiling: Women in the Boardroom: Latin America. Report. Washington, DC: Paul Hastings LLP.

Paxton, Pamela, Melanie M. Hughes, and Matthew A. Painter II. 2010. Growth in Women's Political Representation: A Longitudinal Exploration of Democracy, Electoral System, and Gender Quotas. European Journal of Political Research 49, 1: 25-52.

Presidenta de la República (Chile). 2014. Mensaje no. 076-362 [electoral reform bill]. Santiago, April 22.

Presidente de la Nación (Argentina). 2003. Decreto 222/2003. Buenos Aires, June 19.

Presidente de la República (Nicaragua). 2008. Ley de Igualdad de Derechos y Oportunidades (648-2008). La Gaceta (Managua) 51: March 12.

- 2010. Decreto 29-2010. La Gaceta (Managua) 121: June 28.

Pringle, Rosemary, and Sophie Watson. 1998. "Women's Interests" and the Poststructuralist State. In Feminism and Politics, ed. Anne Phillips. New York: Oxford University Press. 203-23.

Quota Project. n.d. Global Database of Quotas for Women. www.quotaproject.org. Accessed February 19, 2015.

Randall, Vicky. 1998. Gender and Power: Women Engage the State. In Gender, Politics, and the State, ed. Randall and Georgina Waylen. London: Routledge. 185-205.

La República (Lima). 2013. La pareja presidencial enfrenta sin aliados los problemas del tercer ańo del gobierno. July 28. 
Sacchet, Teresa. 2008. Beyond Numbers: The Impact of Gender Quotas in Latin America. International Feminist Journal of Politics 10, 3: 369-86.

Sagot, Montserrat. 2010. Does the Political Participation of Women Matter? Democratic Representation, Affirmative Action, and Quotas in Costa Rica. IDS Bulletin 41, 5: 2534.

Schwindt-Bayer, Leslie. 2009. Making Quotas Work: The Effect of Gender Quota Laws on the Election of Women. Legislative Studies Quarterly 24, 1: 5-28.

2010. Political Power and Women's Representation in Latin America. New York: Oxford University Press.

Thames, Frank C., and Margaret S. Williams. 2013. Contagious Representation: Women's Political Representation in Democracies Around the World. New York: New York University Press.

Tinker, Irene. 2004. Quotas for Women in Elected Legislatures: Do They Really Empower Women? Women's Studies International Forum 27: 531-46.

Towns, Ann. 2012. Norms and Social Hierarchies: Understanding International Policy Diffusion "From Below." International Organization 66, 2: 179-209.

Tribunal Electoral del Poder Judicial de la Federación (Mexico). 2011. Juicios para la protección de los derechos político-electorales del ciudadano. Sentencia SUP-JDC12624/2011. Mexico City.

—. 2013. Representación proporcional en el Congreso de la Unión. Alternancia de géneros para conformar las listas de candidatos. Jurisprudencia 29/2013. Mexico City.

- 2014. Órganos jurisdiccionales electorales locales. Tésis IV/2014. Mexico City.

Waylen, Georgina. 1998. Gender, Feminism, and the State: An Overview. In Randall and Waylen 1998. 1-17.

- 2000. Gender and Democratic Politics: A Comparative Analysis of Consolidation in Argentina and Chile. Journal of Latin American Studies 32, 3: 765-93.

Weldon, S. Laurel. 2002. Beyond Bodies: Institutional Sources of Representation for Women in Democratic Policymaking. Journal of Politics 64, 4: 1153-74.

Zetterberg, Pär. 2008. The Downside of Gender Quotas? Institutional Constraints on Women in Mexican State Legislatures. Parliamentary Affairs 61, 3: 442-60.

. 2011. The Diffusion of Sub-National Gender Quotas and Their Impacts. In Crocker 2011. 53-69. 